原著

\title{
フッ化アンモニウム溶液のヒトエナメル質および ラット実験う蝕におよぼす影響についで
}

\author{
Effect of Ammonium Fluoride on Human Enamel \\ and Rat Experimental Caries
}

\author{
梶田秀 行 $^{* *}$ \\ Hideyuki KAJITA**
}

Received July 16, 1990; accepted July 31, 1990

\begin{abstract}
The purpose of this study was to evaluate the possibility of clinical use for fluoride topical application of dilute ammonium fluoride soluion, in which fluoride concentration was $1 / 3$ times lower than that of APF solution.

Experiments were performed in vitro and in vivo using a solution of phosphoric acid-acidified NH4F (3000 ppm of $\mathrm{F}^{-}, \mathrm{pH} 4.4$ ) and APF (9000 ppm of $\left.\mathrm{F}^{-}, \mathrm{pH} 3.4\right)$. In the experiments on intact enamel, fluoride uptake, acid solubility, and morphological changes in enamel blocks following topical treatment (for $60 \mathrm{~min}$. at $37^{\circ} \mathrm{C}$ ) with fluoride solutions were studied by chemical analysis, scanning electron microscopy, and electron probe X-ray microanalysis. In experiments on rats, the cariostatic effect of ammonium fluoride solution was investigated. Eighteen-day-old male Sprague-Dawley rats were infected with Streptococcus mutans GS-5 for three days and fed a cariogenic diet (Diet 2000 No. 3) during the experimental period. Experimental groups were given topical application of each fluoride solution twice a week. Caries prevalence was examined using a standardized photograph $(\times 50)$ of the rat jaw, and then caries scores (caries incidence and caries extent) were calculated from these data.
\end{abstract}

The fluoride uptake of NH،F-treated enamel surface was a few times higher than that of APFtreated enamel. In the electron probe $\mathrm{X}$-ray microanalysis, the same results were obtained. The acid solubility test proved the acquisition of acid resistance by the enamel. SEM images showed heavy deposits of crystalline material on $\mathrm{NH}_{4} \mathrm{~F}$-treated enamel surface, whereas the deposit was homogeneous in APF-treated enamel.

Both caries incidence and caries extent were clearly reduced, and significantly lower values were found in the fluoride groups than in the control group. The fluoride groups had very few serious grade lesions, whereas the control group had many collapsible lesions.

It is concluded that the topical application of dilute NH,F solution leads to uptake of fluoride into

* 本論文の要旨は平成 2 年 2 月17日第72回岐皁歯科学会例会において発表した。

** 朝日大学齿学部口腔衛生学数室（主任：可児瑞夫教投）

** Department of Preventive Dentistry, Asahi University School of Dentistry (Director: Prof. Mizuo $K A N I)$ 
the enamel surface and proves the acquisition of acid resistance by enamel in vitro, and is effective in reducing caries incidence and inhibiting caries progression in rat experimental caries in vivo. A dilute $\mathrm{NH}_{4} \mathrm{~F}$ solution can be expected to have the same effect as APF in topical application for caries prevention.

索引用語 : フッ化アンモニウム, フッ化物曹面塗布, ラットう蝕, フッ来取り込み, 酸溶解性

Koy words: Ammonium fluoride, Fluoride topical application, Rat caries, Fluoride uptake, Acid solubility

\section{緒言}

現在，う強予防の目的で一般的に用いられているフッ 化物局所応用法としては, フッ化物歯面叙布法, フッ化 物洗口法およびフッ化物配合歯磨剤の使用などがあげら れる1-9)。

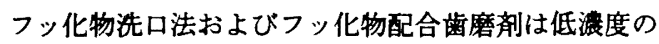
フッ素を使用するため安全性が高く，実施方法が简便で あり，また専門家の手をわずらわせるという繁雑さがな いという利点があるが，一方では，長期間にわたり毎日 実施しなければならないという負担がある。その点, フ ッ化物齿面塗布法は専門家の手をわずらわせるという繁 雑さはあるが, 年 1 回の塗布で効果が期待されるので, 小児に上っては負担の軽い方法であり，フッ化物歯面塗 布法の普及は公衆歯科保健上重要であると思われる。

フッ化物齿面塗布法は, 通常, 一般法ではフッ化物溶 液の塗布時間は 4 分間で, 年 1 回ないし 2 回実施するよ うになっている。この方法は塗布時間が長いので, 幼児 や児童にとっては負担が大きく，また，集団に対する塗 布法の普及を困難にする要因ともなっている。この塗布 時間を短樎できれば, 効率よく多人数に応用できること となり, さらに，フッ素浱度を低下させることができれ ぼ, 安全性も向上することから，フッ化物歯面染布法の 普及の拡大にも役立つものと考えられる。

現在, フッ化物歯面塗布法に用いられているリン酸酸 性フッ化ナトリウム溶液（APF 溶液）は，フッ素灌度 が9,000ppm と高く, また溶液の pH は3.4であり, 安 全性の面ではまだ改善の余地が残されている。

低浱度のフッ化物溶液をエナメル倎に作用させると， フッ素はエナメル犋中に取り込まれフルオロアパタイト あるいはハイドロキシフルオロアパタイトとして安定な 型で存在する 10-14)。フルオロアパタイトの生成は, エナ メル犋アパタイトが難溶性で耐酸性の安定した結晶に移 行することを意味しており，歯エナメル質にう蝕抵抗性 をもたらすためのフッ素のう触予防機序として, 重要な
ものである。

一方, フッ化物崡面塗布法は高湌度のフッ化物溶液を 使用する。フッ素湌度が高い場合はエナメル倎との反応 で，表層に多量のフッ化カルシウム $\left(\mathrm{CaF}_{2}\right)$ を生成し， 症布直後のエナメル質へのフッ素取り込みは非常に大き い。また生成した $\mathrm{CaF}_{2}$ は比較的早期に流出し, 低洗度 のフッ素供給源となり蒾啠と反応してフルオロアパタイ トを生成することにより歯質を安定化させる ${ }^{15-19) 。 ~}$

フッ化アンモニウム溶液をエナメル澌に作用させる と，エナメル犋へのフッ素取り込み量がフッ化ナトリウ 么溶液作用時より高く20-24)，エナメル啠表面に結晶性の 高い顆粒状の $\mathrm{CaF}_{2}$ の沈着が認められている ${ }^{17,20) 。 ま ~}$ た,この $\mathrm{CaF}_{2}$ はフッ化ナトリウム溶液作用により生成 される $\mathrm{CaF}_{2}$ より水に溶出しにくいことも認められてい る $^{20,24)}$ 。さらにフッ化アンモニウム溶液（pH 4.4）は

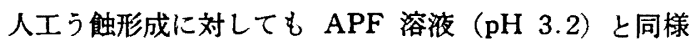
に抑制勃果のあることが報告されている25)。

本教室の山村 ${ }^{26)}$ はリン酸酸性フッ化アンモニウム溶 液 $\left(9,000 \mathrm{ppmF}^{-}, \mathrm{pH} 3.4\right)$ のエナメル質に及ぼす影餢 について APF 溶液と比較検郡したところ，同フッ素港 度, 同 $\mathrm{pH}$ の溶液ではエナメル澌へのフッ素取り込み量 が APF 溶液作用に比べ非常に高く，また $\mathrm{CaF}_{2}$ 生成 量でみるかぎり APF 溶液の $1 / 2$ 以下の時間で APF 溶 液と同様の効果が得られることを示唆している。また加 藤ら ${ }^{27)}$ は APF 溶液の1/3のフッ素濃度のリン酸酸性フ ッ化アンモニウム溶液をエナメル颀粉末に作用させ，エ ナメル所中に多量の $\mathrm{CaF}_{2}$ の生成を認めている。さら に新谷 ${ }^{28)}$ は $\mathrm{APF}$ 溶液と同 $\mathrm{pH}$ でフッ素莀度を $1 / 5$ にし たフッ化アンモニウム溶液をエナメル澌粉末に作用さ せ，フッ素取り込み量， $\mathrm{CaF}_{2}$ 生成およびエナメル質ア パタイトの結晶性，さらに耐酸性効果について比較検討 し，両者の閒に同程度の成績を得ている。

本研究では, フッ化アンモニウム溶液のフッ化物歯面 塗布液としての有用性と臨床応用への可能性を追求する 目的で, 溶液のフッ素濃度を APF 溶液の $1 / 3$ の 3,000 
$\mathrm{ppm}$ とし，pH を4.4に調整したリン酸酸性フッ化アン モニウム溶液について, 実験 1 として intact enamel を 用いてフッ素取り込み番の測定, 酸溶解性試験, エナメ ル質表面の観察を行い，実験 2 としてラットを用いた動 物実験う蝕の抑制効果について検討を行った。

\section{材料および方法}

実験 1 : intact enamel を用いて

実験材料には抜去永久歯（上䫑第一小西）18歯を用 いた。これらの歯をロビンソンブラシを用いて清掃し，

エナメル犋の煩面および舌面が実験歯面となるように長 軸方向に2 分割した。次いで超音波洗浄を行った後， ナメル啠表面を露出させ他の面は wax で被覆し実験試 料とした。

作用溶液は半井化学薬品社製フッ化アンモニウムを用 いて $157.9 \mathrm{mM} \mathrm{NH}$ F 溶液（フッ素湴度理論值 3,000 $\mathrm{ppm}, \mathrm{pH}$ 4.4) 扩よび MERCK 社製フッ化ナトリウム を用いて APF 溶液 (フッ素灌度理論値9,000ppm, pH 3.4）を調製し使用した。溶液の $\mathrm{pH}$ は正リン酸を用い て調整した。また，対照群には精製水を用いた。

エナメル片に各溶液を $37^{\circ} \mathrm{C}$ で60分間作用させ，作用 後精製水にて十分水洗を行った後, 直径 $2.5 \mathrm{~mm}$ の window を作製した。

（1）フッ素取り込み量の測定

試料を $0.5 \mathrm{M}$ 過塩素酸溶液 $2 \mathrm{~m} l$ 中に愚垂し，15, 40 ,

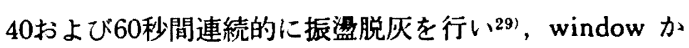
ら溶出するフッ素量とカルシウム量を測定した。

フッ素の測定は McCann の方法 ${ }^{30} に$ 淮じて上記脱灰 液 $0.5 \mathrm{~m} l$ に0.2 $\mathrm{ppmF}^{-}$となるように $\mathrm{NaF}$ 溶液を添加 した $0.5 \mathrm{M}$ クエン酸ナトリウム溶液 $2 \mathrm{ml}$ を加え、イオ ン電極法により行った。测定には ORION 社製イオナ ライザ901型ならびにフッ素複合電極96-09型を用いた。 カルシウムの定量は原子吸光光度法により行った。測定 には日立偏光ゼーマン原子吸光光度計 (HITACHI Polarized Zeeman 180-80形) を用い, リンの妨害除去の ため硝酸ランタン（ランタン終濃度 $2000 \mu \mathrm{g} / \mathrm{ml}$ ）を添加 した。脱灰エナメル犋の表層か门の深さは，エナメル倎 のカルシウム含有量を $36.0 \%$, 比重を $2.95^{311}$ としてこれ らの測定値から算出した。

（2）酸溶解性試験

$0.4 \mathrm{M}$ 酢酸一酢酸ナトリウム緩衙液（ $\mathrm{pH} 4.0 ） 20 \mathrm{~m} l$ 中に試料を照垂し, $37^{\circ} \mathrm{C}$ 恒温槽中で180分間振篮脱灰し て酸溶解性試験を行った。その間, 正確に30分ごとに緩 衙液 $2 \mathrm{ml}$ を採取し, 溶出するリン量を測定した。
リンの定量は, $p$-aminodiphenylamine monohydrochloride を用いる Dryer らの方法 ${ }^{32}$ に従って, 分光光 度計 (HITACHI 124型) を用いて波長350nm にて比 色定量を行った。各脱灰液 $2 \mathrm{~m} l$ 中の溶出リン量からそ れぞれの脱灰時間までに溶出した総リン量を算出し，エ ナメル梊の酸抵抗性の指標とした。

\section{（3）走査電子顕微鏡観察}

フッ化物溶液作用エナメル梊表面および，作用面の酸 抵抗像を観察する目的で，薬液作用直後および酸溶解性 試験後の切片を試料とした。各試料は水洗乾燥, 上年 アルコール脱水ののち, イオンスパッタ装睓により直流 $1.2 \mathrm{kV}, 5 \mathrm{~mA}$ にて 6 分間のゴールド蒸着を行い, 走查 電子影微鏡（JEOL，JSM-35C）を用いて加速電圧 15 $\mathrm{kV}$, 倍率3,000倍でエナメル梊表面の锶察を行った。

(4) X線マイクロアナライザ分析

フッ化物溶液作用後および酸溶解性試験後のエナメル 蜇中の各元素の分布状態を検索するためにX線マイク口 アナライザによる線分析を行った。試料は通法に従い上 䄯アルコール脱水を行い, スチレンモノマー, ポリエス テル樹脂（BPS レジン, 京都科学標本）に浸漬の後, ポリエステル樹脂包埋を行った。硬化後エナメル質表面 に垂直に切断し，断面を鏡面研磨した。研磨切片は導電 性接着剤（JEOL，ドータイト）を用いて試料台に固定 し, 真空蒸着装置 (SHIMADZU, EA-250GP) にて 100〜150Å の厚さにカーボン蒸着をほどこした。次い で Table 1 に示す測定条件にて，X線マイクロアナラ イザ (SHIMADZU, EMX-SM) によりカルシウム,リ ン,フッ秦の線分析を行った。

Table 1 Experimental conditions of electron probe $\mathrm{X}$-ray microanalysis

\begin{tabular}{|c|c|c|}
\hline \multicolumn{2}{|c|}{ Accelerating voltage } & $20 \mathrm{kV}$ \\
\hline \multicolumn{2}{|c|}{ Specimen current } & $0.05 \mu \mathrm{A}$ \\
\hline \multicolumn{2}{|l|}{ Take off angle } & $52.5^{\circ}$ \\
\hline \multicolumn{2}{|l|}{ Beam diameter } & $2.5 \mu \mathrm{m}$ \\
\hline \multicolumn{2}{|l|}{ Scanning speed } & $20 \mu \mathrm{m} / \mathrm{min}$ \\
\hline \multicolumn{2}{|l|}{ Chart speed } & $20 \mathrm{~mm} / \mathrm{min}$ \\
\hline $\begin{array}{c}\text { Characteristic } \\
\text { X-rays }\end{array}$ & $\begin{array}{c}\text { Analysing } \\
\text { crystal }\end{array}$ & $\begin{array}{c}\text { Count full } \\
\text { scale }\end{array}$ \\
\hline CaKa & LiF & $1 \times 10^{4}$ \\
\hline PKa & $A D P$ & $1 \times 10^{4}$ \\
\hline$F K_{\alpha}$ & RAP & 100,500 \\
\hline
\end{tabular}

実験 $2 ：$ ラットを用いた動物実験

1) 実験材料

（1）実験動物 
実験には同ファミリー, 15 日龄の SD 系雄ラット 180 匹を使用した。これらのラットは室温 $22 \pm 2{ }^{\circ} \mathrm{C}$, 湿度 $50 \pm 5 \%$ 一定環境下で飼育した。

(2) 飼料

普通粉末飼料 CE-2（日本クレア社製）抽よびう触誘 発性飼料 Diet 2000 No. 338（日本クレア社製）を用い た。すなわち，実験開始時よりラットの離乳時（20日

龄）までは CE-2 を，以後実験終了時までは Diet 2000 No. 3 を与え飼育した。なお飼料および飲料水は自由搨 取上した。

（3）接種菌および接種菌液

接種菌は本学口腔細菌学教室より分与をうけた Stre ptococcus mutans GS-5 株 ${ }^{34)}$ である。接種菌液の調彆は 可児らの方法 ${ }^{351}$ に従い行った。すなわち，0.5\% Yeast Extract（Difco 社）を加えた $1,000 \mathrm{~m} l$ の Trypticase Soy Broth（BBL 社）で接種菌を16時間培荃し，その 培養菌液を $10,000 \times \mathrm{g}$ にて10分間遠心分離することによ り集菌し，生理食塩水で 3 回洗浄後, $20 \mathrm{~m} l$ の滅菌生理 食塩水に㦟濁したものを用いた。この慗濁液中には比濁 法によると $3 \times 10^{7}$ 個の菌が存在する。

\section{（4）塗布液}

フッ化物菌面等布液は実験 1 と同様に $157.9 \mathrm{mM} \mathrm{N}$ $\mathrm{H}, \mathrm{F}$ 溶液（フッ素湿度理論值 $3,000 \mathrm{ppm}, \mathrm{pH} 4.4$ ) およ び APF 溶液（フッ素濃度理論值 $9,000 \mathrm{ppm}, \mathrm{pH} 3.4$ ) を使用した。対照群には精製水を用いた。

\section{2）実験方法}

実験スケジュールは Fig. 1 に示すとおりである。な

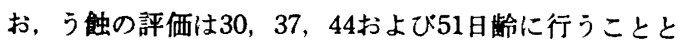
した。

（1）菌の接種および定着状態

18 日龄より 3 日間毎日ラット口腔内に接種菌液 0.1 $\mathrm{m} l$ を商下接種するとともに，その間の㰣料水中にも菌 液 $1 \mathrm{~m} l / 200 \mathrm{~m} l$ を混入し菌の接種を行った。

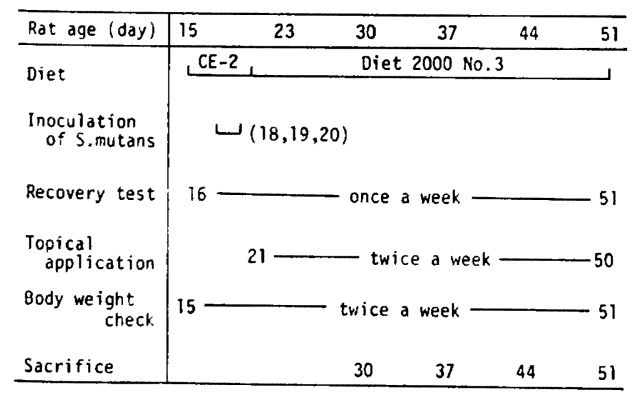

Fig. 1 Schedule of rat experimental caries
ラット口腔内の接種菌の定着状態は菌接種後週 1 回の 割合で観察した。すなわちラットの臼歯を綿棒で清拭し たものを陚料とし，それを Mitis Salivarius Agar（Difco 社）に Sucrose が最終瀑度20\%となるように, さら にバシトラシンを 0.25 単位 $/ \mathrm{ml}$ 添加36)した MSB20S 培 地に接種し， $37^{\circ} \mathrm{C} に て 2$ 日間嫌気的に培養を行い, コ ロニーの有無を観察した。なお、菌接種前の口腔内細菌 暏の状態を観察するため16日龄にも同操作を行った。

(2) 菌面染布

ラットは60匹ずっ 3 群に分けてそれぞれ $\mathrm{NH}_{4} \mathrm{~F}$ 溶液 染布群 (以下 $\mathrm{NH}_{4} \mathrm{~F}$ 群), $\mathrm{APF}$ 溶液塗布群 (以下 $\mathrm{APF}$ 群）ならびに精製水叙布群（以下対照群）とした。

薬液塗布は菌接種後週 2 回の割合で行った。したがっ て30，37，44および51日龄では染布回数はそれぞれ4，

$6 ， 8$ ）よび10回となる。叙布方法はラットを非麻醉下 で強制開口させ，薬液をしみ込ませた綿球を用いて直接 ラットの上下臼歯部に塗布を行った。また，塗布後30分 間は飼料および飲料水の供給を絶った。

（3）う鳋の評価法

実験期間終了後のラットは直ちにエーテル麻酔下で屠 殺後断頭し，10\%ホルマリン溶液で固定後，軟組織を除 去して上下顥骨をとり出しう触の観察を行った。

う強の評価は従来より当教室で実施している方法 ${ }^{37} に$ 従い行った。すなわち Fig. 2 に示すように, ラット

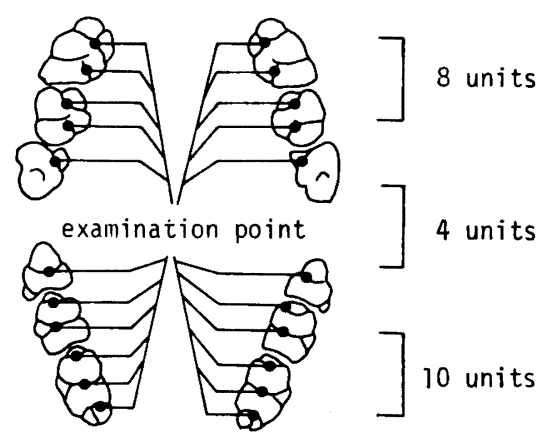

Fig. 2 Caries score chart of rat molars

Table 2 Scoring of rat caries lesions Grade

0 : Non caries

1 : Subsurface lesion

2 : Enamel lesion

3 : Lesion with dentinal involvement

4 : Lesion penetrated to pulp

5 : Destruction of cusp 
臼歯咬合面裂溝部のう触好発部位を上買10unit, 下罰 12 unit と定め, 各部位に発生するう触の進行状態を Table 2 に示す 5 段階に分け, 顕微鏡写真振影装置（MICROFLEX，UFX-II．Nikon）を用いカラー写真振影 を行った。

なお，ラットの第 3 臼歯の萌出は33日齢前後であるた め, 30 日齢群では第 1, 第 2 臼歯のみのう強診査を行っ た。したがって30日齢群では上䫂 8 unit, 下影10unit が 判定対象である。

う鳋の診査は写真上で $\mathrm{NH}_{4} \mathrm{~F}$ 群, $\mathrm{APF}$ 群および対照 群が明らかでない状热にして，各 unit のう䖵の有無な らびにう触 grade の判定を行った。この成䋹から各日 龄におけるう䖵の発生状況 (caries incidence), 進行状 態 (caries extent) およびう強䍜患程度 (caries grade) の割合を算出して比較検郡を行った。群間の有意差検定 は t-testを用いた。

\section{成 綪}

実験 1 ：intact enamel を用いて

(1) フッ素取り込み量の測定

フッ化物溶液作用群，および対照群の第 1 層から第 4 層までのフッ素量の测定値を Fig. 3 および Table 3 に示した。

$\mathrm{NH}_{4} \mathrm{~F}$ 群は APF 群と比ベフッ素取り込み量が非常 に高い値であった。すなわち, APF 群第 1 層の $4.94 \mu \mathrm{m}$ の深さで8,684ppm であったのに対し， $\mathrm{NH}_{4} \mathrm{~F}$ 群では， 表層から $0.27 \mu \mathrm{m}$ の第 1 層で63,499ppm, 8.58 $\mu \mathrm{m}$ の第 2 層でも26,936ppm のフッ素取り込み量を示した。ま た, $\mathrm{NH}_{4} \mathrm{~F}$ 群は $0.5 \mathrm{M}$ 過塩素酸に対して耐酸性が高く， 脱灰哚さは第 4 層までの155秒間で APF 群および対照 群のそれぞれ1/3，1/4であった。

(2) 酸溶解性試験

Window method を用い, 值径 $2.5 \mathrm{~mm} の$ window から0.4M 酢酸一酢酸ナトリウム緩衝液（ $\mathrm{pH} 4.0 ２ 0$

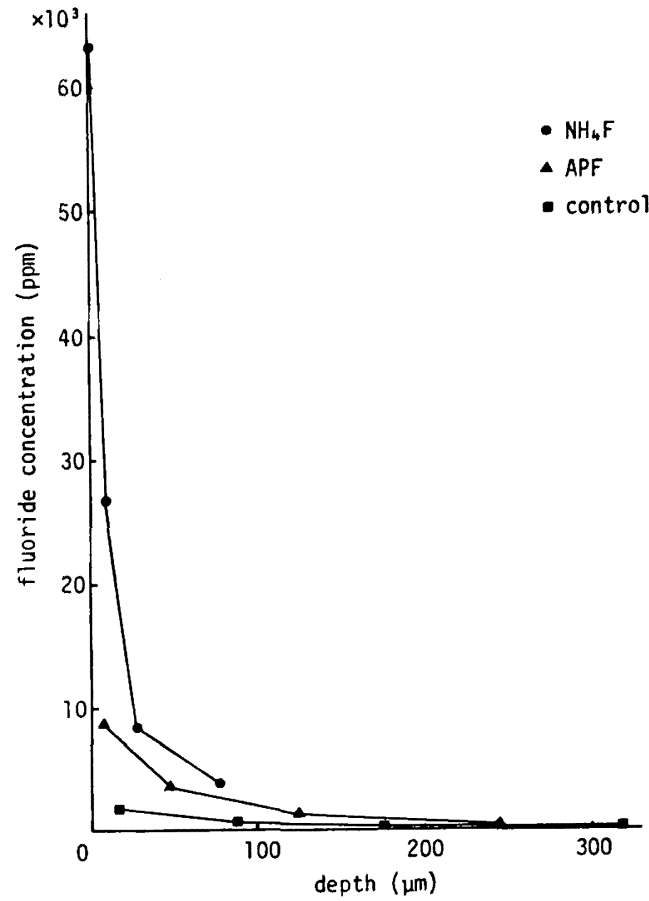

Fig. 3 Fluoride concentration in human enamel treated with fluoride solutions

$\mathrm{m} l$ 中に溶出したリン量を経時的に測定し，酸抵抗性の 指標とした (Fig. 4, Table 4)。

フッ化物溶液作用群は対照群に比較していずれもリン の溶出が少なく，特に $\mathrm{NH}_{4} \mathrm{~F}$ 群では高い酸溶解性の抑 制が喼められた。また，対照群とフッ化物溶液作用群の 溶出リン量の比から $\mathrm{NH}_{4} \mathrm{~F}$ 群と APF 群の耐酸性を比 較すると，APF 群では経時的変化が少なく，一貫して $2 \sim 3$ 倍の耐酸性を示したが, $\mathrm{NH}_{4} \mathrm{~F}$ 群では脱灰初期の 30 分後，60分後に扔いて耐酸性が高く，対照群の約 12 倍，APF 群の約 4 倍の值を示した。また経時的に耐酸 性の低下は認められるが180分後でも対照群の約4.5倍,

Table 3 Mean fluoride concentration in human enamel treated with fluoride solutions

\begin{tabular}{c|rr|rr|rr}
\hline & \multicolumn{2}{|c|}{$\mathrm{NH}_{4} \mathrm{~F}$} & \multicolumn{2}{|c|}{ APF } & \multicolumn{2}{c}{ control } \\
\hline layer & $\operatorname{depth}(\mu \mathrm{m})$ & $\mathrm{F}^{-}(\mathrm{ppm})$ & $\operatorname{depth}(\mu \mathrm{m})$ & $\mathrm{F}^{-}(\mathrm{ppm})$ & $\operatorname{depth}(\mu \mathrm{m})$ & $\mathrm{F}^{-}(\mathrm{ppm})$ \\
\hline 1 & 0.27 & 63499 & 4.94 & 8684 & 15.79 & 1675 \\
2 & 8.58 & 26936 & 47.80 & 3417 & 86.27 & 581 \\
3 & 26.21 & 8387 & 122.44 & 1298 & 176.63 & 256 \\
4 & 75.90 & 3838 & 245.84 & 303 & 317.54 & 74 \\
\hline
\end{tabular}




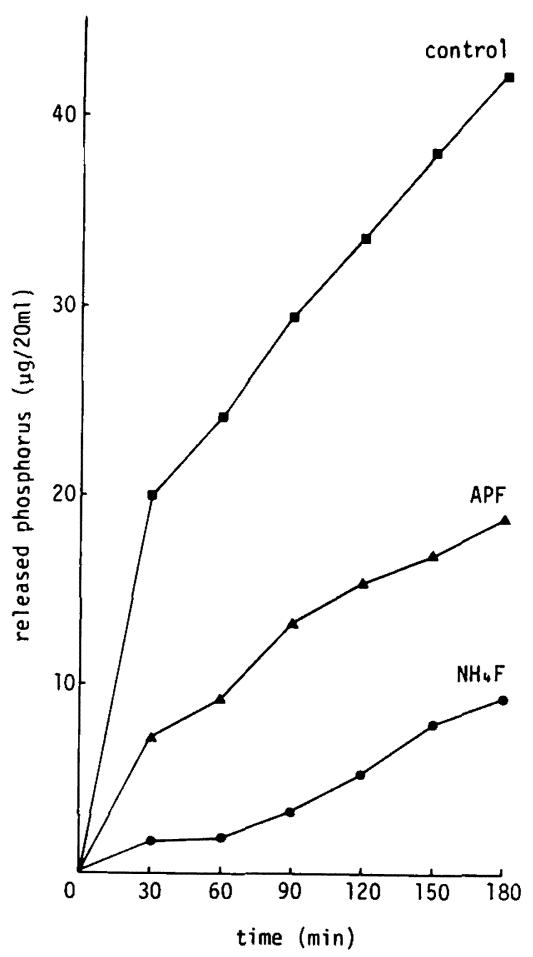

Fig. 4 Phosphorus released into $0.4 \mathrm{M}$ acetate buffer ( $\mathrm{pH} 4.0$ )

Table 4 Amount of phosphorus released into $0.4 \mathrm{M}$ acetate buffer ( $\mathrm{pH} 4.0$ )

\begin{tabular}{c|ccc}
\hline time $(\min )$ & $\mathrm{NH}_{4} \mathrm{~F}$ & \multicolumn{1}{c}{ APF } & control \\
\hline 30 & 1.58 & 7.18 & 19.91 \\
60 & 1.91 & 9.20 & 24.22 \\
90 & 3.25 & 13.22 & 29.52 \\
120 & 5.28 & 15.40 & 33.65 \\
150 & 8.03 & 16.81 & 37.87 \\
180 & 9.49 & 18.77 & 42.19 \\
\hline \multicolumn{4}{|c}{} \\
\hline
\end{tabular}

APF 群の約 2 倍の值であった (Fig. 5)。

（3）走查電子顕微鏡観察

フッ化物溶液作用植後および酸溶解性試験後のエナメ ル質表面の SEM 観察を行った (Fig. 6)。対照群の作 用直後の SEM 像ではゆるやかな凹凸を示す周波条の像 が観察されたが，APF 溶液作用直後のエナメル表面は $\mathrm{CaF}_{2}$ と思われる顆粒状の生成物が沈着していた。一方, $\mathrm{NH}_{4} \mathrm{~F}$ 溶液作用直後の SEM 像では表面は生成物の厚 い層で覆われており，APF 溶液作用で㓋察された像と は異なり，細かい粒子が繳密に重なりあった像が認めら

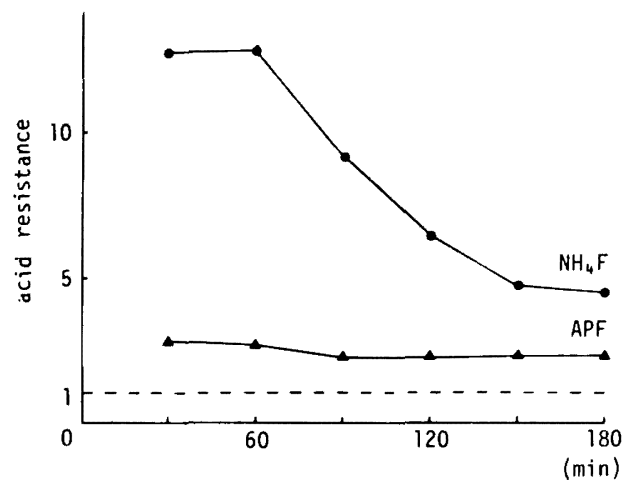

Fig. 5 Acquisition of acid resistance by human enamel with fluoride solutions

れた。

酸浴解性訊験後のエナメル啠表面の SEM 像では対照 群は明らかな脱灰像を示した。APF 群では耐酸性を示 寸像が観察されたが, $\mathrm{NH}_{4} \mathrm{~F}$ 群では顆粓状沈着物の残留 が琶められ，APF 群より高い酸抵抗像が確慧された。

（4）X線マイクロアナライザ分析

フッ化物溶液作用直後および酸溶解性試験後のエナメ ル倎中のカルシウム, リン, フッ素の分布状態について は EPMA による線分析を行った (Fig. 7)。

作用直後では対照群はカルシウム, リンが表層から内 層にわたって均一な分布状態を示し，フッ素のピークは 認められなかった。APF 群ではカルシウム, リンは対 照群と比べ差異は認められなかったが，フッ素ではFK $\alpha$ 線が表層から $10 \mu \mathrm{m}$ の媣さで高いピークを示し，約 $30 \mu \mathrm{m}$ の深さまでフッ素が取り込まれていることが示された。 $\mathrm{NH}_{4} \mathrm{~F}$ 群ではエナメル質表層約 $10 \mu \mathrm{m}$ にFK $\alpha$ 線と $\mathrm{CaK} \alpha$ 線の高いピークが出現し，同部位で $\mathrm{PK} \alpha$ 線のピークの 低下が琶められた。また, $\mathrm{NH}_{4} \mathrm{~F}$ 群の $\mathrm{FK} \alpha$ 線の count full scale は APF 群の 5 倍であることからみて, エナ メル啠へのフッ素取り込みは $\mathrm{NH}_{4} \mathrm{~F}$ 群の方が $\mathrm{APF}$ 群 より数倍大きいことが示された。

酸溶解性試験後の試料では対照群, APF 群ともに $\mathrm{CaK} \alpha$ 線, $\mathrm{PK} \alpha$ 線の低下が認められ脱灰像が観察され たが, NH、F 群は最表層にフッ素のピークが認められ, また表層から数 $10 \mu \mathrm{m}$ の深さまでフッ素が浸透してい る像が 示された。さらに表層下 $30 \mu \mathrm{m}$ の深さの 所では $\mathrm{CaK} \alpha$ 線， $\mathrm{PK} \alpha$ 線が低下し，脱灰像が観察された。

実験 2：ラットを用いた動物実験

（1）门钫発生状況 (caries incidence)

Caries incidence はう蝕発生 unit 数で示した (Fig. 8, Table 5)。 
650
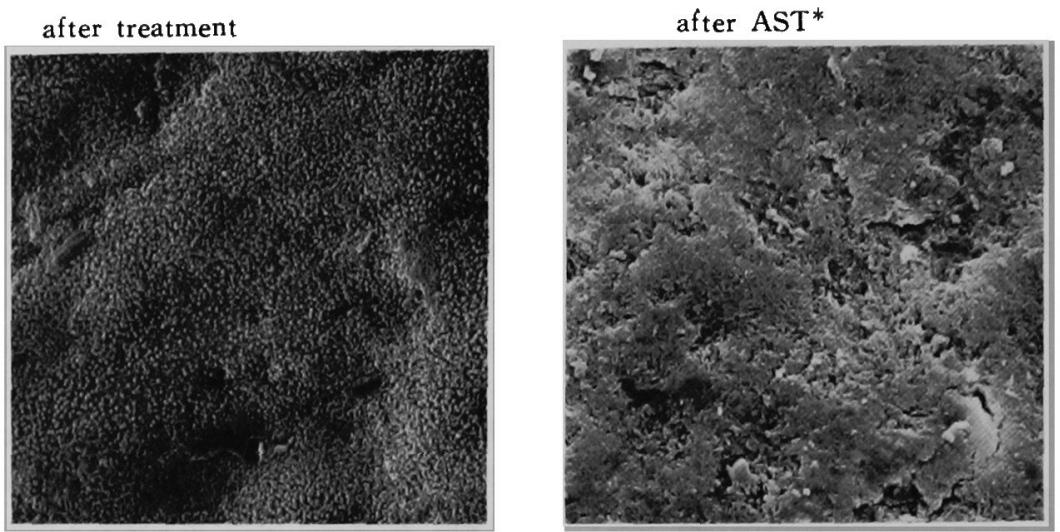

$\mathrm{NH}_{4} \mathrm{~F}$
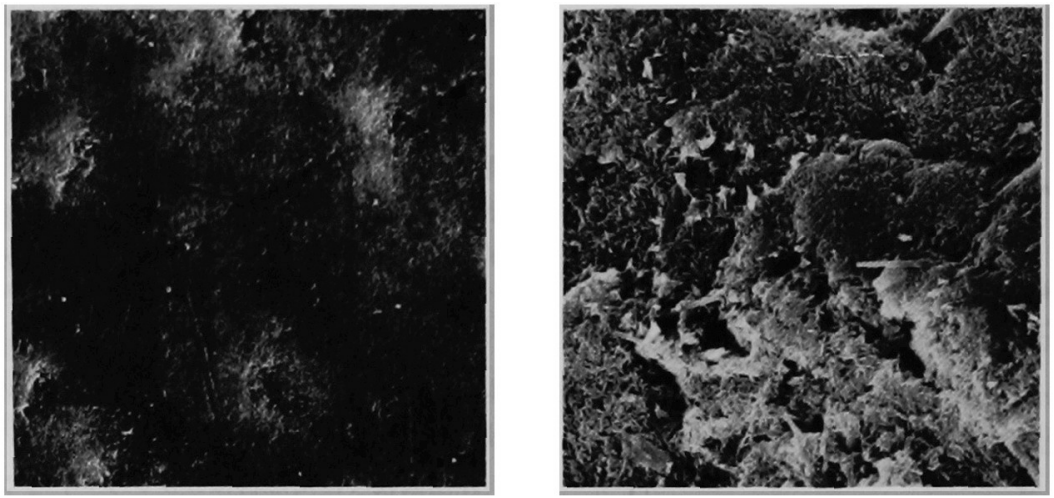

APF

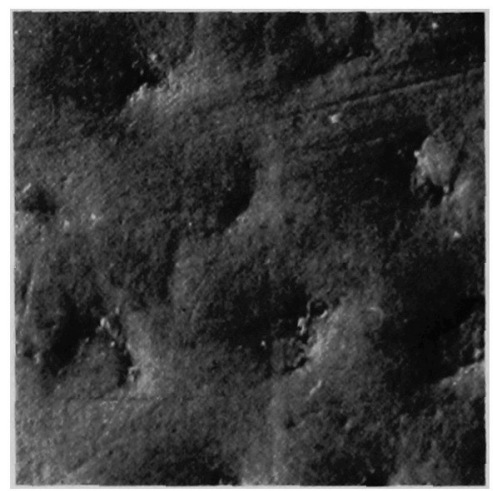

$10 \mu \mathrm{m}$

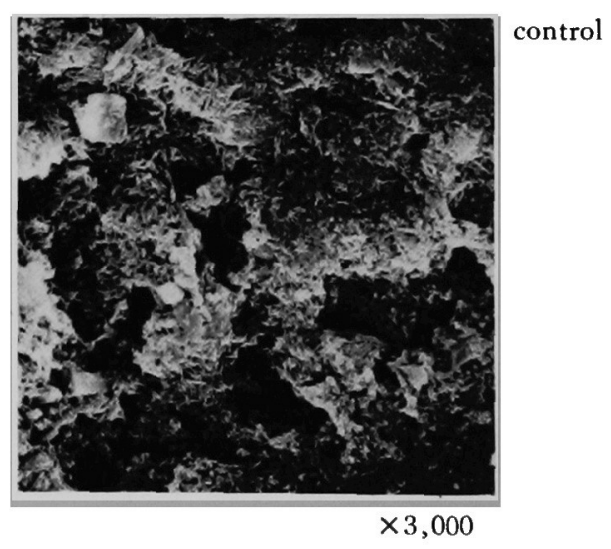

Fig. 6 SEM images of enamel surface, ${ }^{*}$ AST : acid solubility test

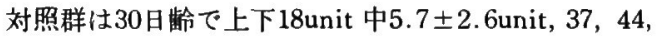
51 日㱓で 22 unit 中それぞれ $11.0 \pm 3.2$ unit, $19.4 \pm 2.0$

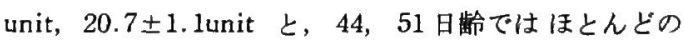
unit でら蝕発生が認められた。

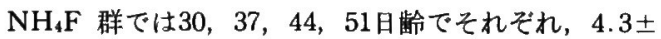
2.9unit, 9.3 2 2.6unit, $18.5 \pm 1.6$ unit, $18.5 \pm 1.8$ unit とう蜆の発生は抑制され，51日蹂では対照群に比べ危険
率0.1\%以下で統計的に 有意の差でう蝕発生が 抑制され た。

一方 APF 群では44日鮯まではう蝕発生が著しく抑制 されており，30日㱓では 18 unit 中わずか $2.1 \pm 1.6 u n i t$ の発生を認めたにすぎなかった。また44日秢では15.4士 4. lunit と NH4F 群と比較しても危険率 $5 \%$ 以下で発 生抑制がみられた。 

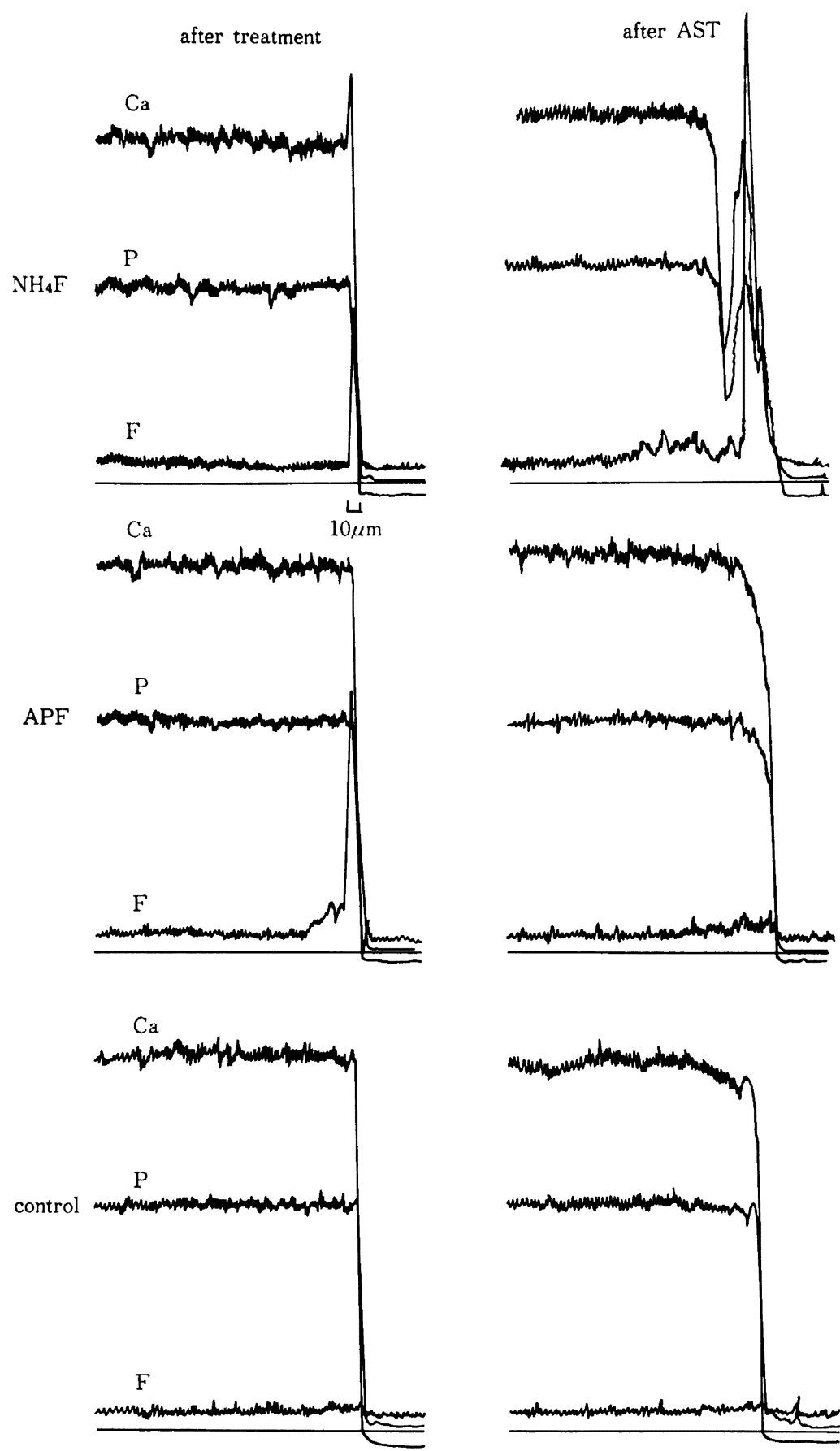

Fig. 7 Distribution patterns of $\mathrm{Ca}, \mathrm{P}$, and $\mathrm{F}$ in enamel revealed by EPMA

またう蝕䍜患率（う蝕䍜患 unit 率）は対照群では37 日龄ですでに $50.0 \%$ であり，51 日齡では $94.2 \%$ を示し た。 NH4F 群では，44日龄から51日龄でう触発生が抑制
されており，ともに $84.2 \%$ をした。APF 群ではほぼ 直線的に䍜患率は增加しており51日龄では $\mathrm{NH}_{4} \mathrm{~F}$ 群以 上の罹患率を示した（Table 6)。 
Table 5 Caries incidence scores in each group

\begin{tabular}{|c|c|c|c|c|}
\hline & & maxilla & mandible & total \\
\hline \multirow{2}{*}{ 30-day-age } & & $1.5 \pm 1.57]^{\star}$ & $2.8 \pm 2.0$ & $4.3 \pm 2.97]^{\star}$ \\
\hline & APF & $0.3 \pm 0.7$ & $1.8 \pm 1.6$ & $\begin{array}{l}2.1 \pm 1.6 \\
5.7+2.6\end{array}$ \\
\hline & cominot & & & \\
\hline \multirow{3}{*}{ 37-day-age } & $\mathrm{NH}_{4} \mathrm{~F}$ & $3.5 \pm 1.8$ & $5.7 \pm 1.5$ & $9.3 \pm 2.6$ \\
\hline & APF & $2.8 \pm 1.3$ & $5.4 \pm 1.5$ & $8.3 \pm 2.5^{\star}$ \\
\hline & control & $4.9 \pm 2.1$ & $6.1 \pm 1.6$ & $11.0 \pm 3.2$ \\
\hline \multirow{3}{*}{ 44-day-age } & $\mathrm{NH}_{4} \mathrm{~F}$ & $7.9 \pm 1.47_{*}$ & $10.7 \pm 1.47 *$ & $18.5 \pm 1.67 *$ \\
\hline & APF & $6.2 \pm 2.2 \star\rfloor$ & $9.2 \pm 2 . \stackrel{\star}{3}\rfloor$ & $15.4 \pm 4.1]$ \\
\hline & control & $8.3 \pm 0.7$ & $11.1 \pm 2.4$ & $19.4 \pm 2.0$ \\
\hline \multirow{3}{*}{ 51-day-age } & $\mathrm{NH}_{4} \mathrm{~F}$ & $7.8 \pm 0.7$ & $10.7 \pm 1.3$ & $18.5 \pm 7^{\star \star \star} .8$ \\
\hline & APF & $7.9 \pm 1.7$ & $10.9 \pm 2.1$ & $18.8 \pm 3.4$ \\
\hline & control & $8.9 \pm 0.8$ & $11.0 \pm 0.5$ & $20.7 \pm 1.1$ \\
\hline
\end{tabular}

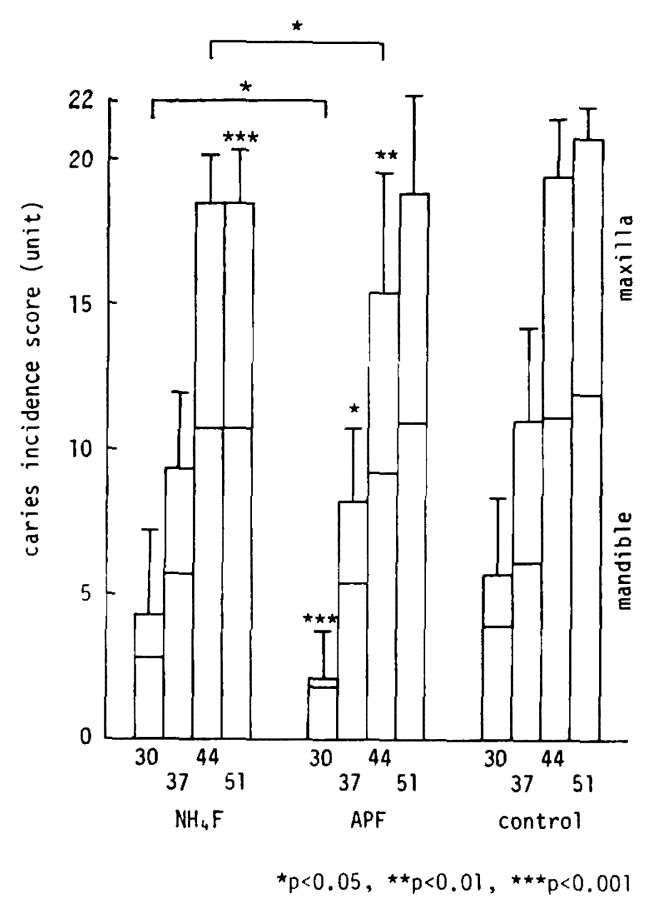

Fig. 8 Comparison of caries incidence scores
（2）う触進行状態 (caries extent)

Caries extent は各 unit $の$ caries grade の合計で表し た (Fig. 9, Table 7)。

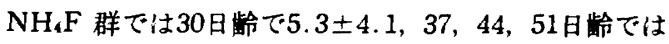

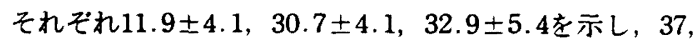
44日龄で対照群の $19.0 \pm 7.3 ， 39.7 \pm 10.3$ と比較すると 危険率 $1 \%$ 以下で，51日龄の $46.8 \pm 7.7$ と比較すると危 険率 $0.1 \%$ 以下でそれぞれ 統計的に有意の進行抑制勃果 が認められた。

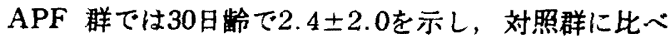
危険率 $0.1 \%$ 以下で, $\mathrm{NH}_{4} \mathrm{~F}$ 群と比較しても $5 \%$ 以下で 有意に進行抑制効果が認められた。また，44 日龄でも $23.3 \pm 8.9$ を示し， $\mathrm{NH}_{4} \mathrm{~F}$ 群と比較しても危険率 $1 \%$ 以 下で進行抑制効果が認められた。

（3）う触䍜患程度 (caries grade) の割合

う強の各 grade の分布状眧はフッ化物溶液塗布群で は対照群に比べ，すべての日龄で caries grade は低く， う触は軽症であることが示された (Fig. 10, Table 8)。 初期う触を示す grade 1 についてみると, $\mathrm{NH}_{4} \mathrm{~F}$ 群で は30日齡で80.0\%，37，44，51日踚でそれぞれ74.1， $34.9 ， 28.1 \%$ を示し，対照群の67.0，42.4，25.4，15.4 \%と比較すると明らかに高く，う蝕進行抑制効果の高

Table 6 Caries prevalence rate at each rat age

\begin{tabular}{lcccc}
\hline & 30-day-age & 37-day-age & 44-day-age & 51-day-age \\
\hline $\mathrm{NH}_{4} \mathrm{~F}$ & 24.1 & 42.1 & 84.2 & 84.2 \\
APF & 11.9 & 37.3 & 70.0 & 85.5 \\
control & 31.5 & 50.0 & 88.2 & 94.2 \\
\hline
\end{tabular}


Table 7 Caries extent scores in each group

\begin{tabular}{|c|c|c|c|c|}
\hline & & $\operatorname{maxilla}$ & mandible & total \\
\hline \multirow{3}{*}{ 30-day-age } & $\mathrm{NH}_{4} \mathrm{~F}$ & $1.7 \pm 1.77_{\star \star \star}$ & $3.6 \pm 3.3$ & $5.3 \pm 4.1]^{\star}$ \\
\hline & APF & $0.3 \pm 0.7]^{\star \star}$ & $2.1 \pm 2^{\star \star \star} .0$ & $\left.2.4 \pm 2^{\star *} .0^{\star}\right]$ \\
\hline & control & $2.1 \pm 1.8$ & $6.0 \pm 3.4$ & $8.1 \pm 4.1$ \\
\hline \multirow{3}{*}{ 37-day-age } & $\mathrm{NH}_{4} \mathrm{~F}$ & $3.9 \pm 2.2$ & $8.1 \pm 2 . \stackrel{\star}{9}$ & $11.9 \pm 4.17$ \\
\hline & APF & $2.9 \pm 1^{\star \star \star \star}$ & $7.2 \pm 2 . \overline{5}$ & $10.1 \pm \stackrel{\star \star \star * \star *}{3.3}$ \\
\hline & control & $7.5 \pm 4.2$ & $11.5 \pm 3.7$ & $19.0 \pm 7.3$ \\
\hline \multirow{3}{*}{ 44-day-age } & $\mathrm{NH}_{4} \mathrm{~F}$ & $\left.12.6 \pm 3^{\star \star 2}\right]^{\star}$ & $18.1 \pm 3.2^{ \pm}$ & $\left.30.7 \pm 4^{*} .^{\star}\right]_{\star \star *}$ \\
\hline & APF & $8.8 \pm \stackrel{* \star \star *}{4.4}]$ & $14.5 \pm 5.7\rfloor$ & $23.3 \pm 8.8 \pm .9]$ \\
\hline & control & $17.3 \pm 4.9$ & $22.5 \pm 6.7$ & $39.7 \pm 10.3$ \\
\hline \multirow{3}{*}{ 51-day-age } & $\mathrm{NH}_{4} \mathrm{~F}$ & $13.7 \pm 2.6$ & $19.2 \pm \frac{\pi^{\star \star *}}{3.4}$ & $32.9 \pm \pm 5^{\star \star \star} .4$ \\
\hline & APF & $12.6 \pm 3^{\star \star \star} .7$ & 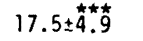 & 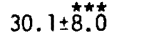 \\
\hline & control & $18.7 \pm 3.9$ & $28.1 \pm 4.7$ & $46.8 \pm 7.7$ \\
\hline
\end{tabular}

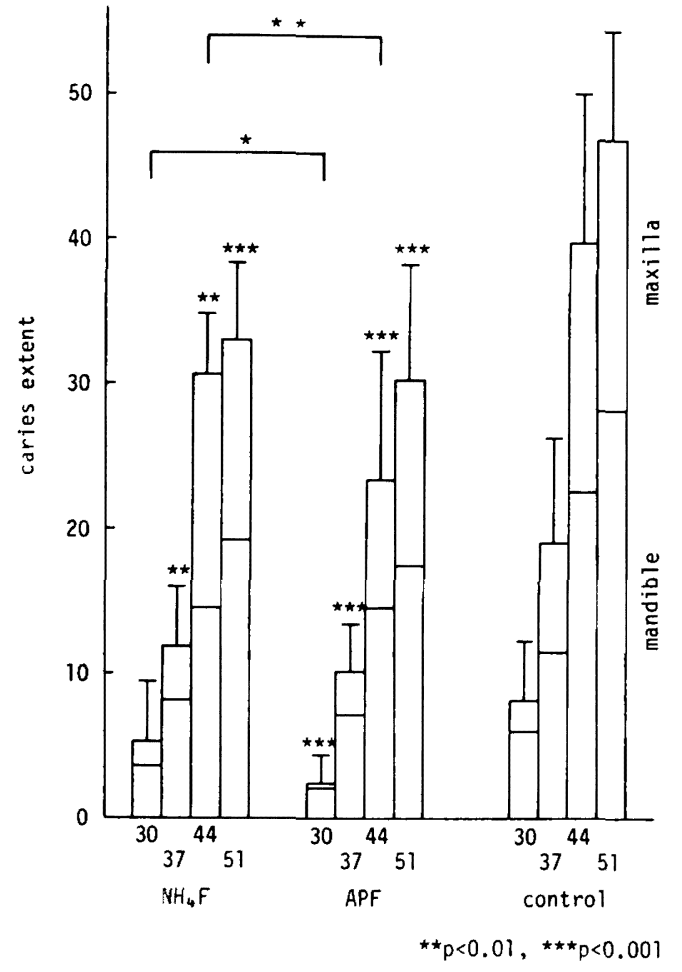

Fig. 9 Comparison of caries extent

いことが認められた。また，対照群は重症う蝕を示す grade 4 以上のう蝕がすでに30日龄より存在し，以後日 跉がすすむにつれ割合は增加し，最終屠殺日の51日㱓で は7.4\%を示した。 NH、F 群は重症う䖪が37日龄でわず か0.7\%存在したにすぎず，日㱓がすすんでも以後重症
う触は認められなかった。一方 APF 群では実験期間を 通して重症う蝕は認められなかった。

（4）菌の定着状態および発育状热につい下

菌の定着についてはコロニーの有無を観察した。各群 ともに菌接種前の 16 日龄では菌の存在を認めなかった が，菌接種後は各日龄で菌の定着が確認された（Table 9)。

実験期間中ラットの健康状態を把握する目的で定期的 に体重測定を行った。ラットの体重は実験開始時より順 調に増加し, フッ化物溶液塗布群と対照群の間に体重增 加の差は認められなかった（Fig. 11）。また，各群とも 飼料，飲料水の捸取状恏に差はなく，疾病の兆候をもつ ラットは認められなかった。

\section{考察}

フッ化アンモニウム化合物のエナメル澌耐酸性付与効 果についての研究は，1949年 Manly ら 381 にってはじ まり， $\mathrm{pH} 3.5$ の $\mathrm{NH}_{4} \mathrm{HF}_{2}$ 溶液は中性 $\mathrm{NaF}$ 溶液よりエ ナメル倎人の耐酸性付与効果が高いことが報告されてい る。しかしこれはpH の差によるものとも考えられてい た。Muhlemann ら ${ }^{34}$ は同 $\mathrm{pH}(2.9)$ の $\mathrm{NH}_{4} \mathrm{HF}_{2}$ 溶液 と $\mathrm{NaF}$ 溶液を比較し, $\mathrm{NH}_{4} \mathrm{HF}_{2}$ 溶液の方が耐酸性付与. 効果が大きいことを認め, さらに $\mathrm{NH}_{4} \mathrm{~F}$ 溶液と $\mathrm{NaF}$ 溶液を比較した場合でも，耐酸性付与効果は $\mathrm{NH}_{4} \mathrm{~F}$ 群 で有意に大きいことを示している。またここのことによ り $\mathrm{NH}^{+}$が何らかの役割を演じているのであろうと考 察している。

フッ化アンモニウムに関しての研究は 1970 年代より 
Table 8 Percentage of the caries grades at each rat age

\begin{tabular}{lllllll}
\hline & & 1 & 2 & 3 & 4 & 5 \\
\hline \multirow{3}{*}{ 30-day-age } & $\mathrm{NH}_{4} \mathrm{~F}$ & 80.0 & 18.5 & 1.5 & 0.0 & 0.0 \\
& APF & 87.5 & 12.5 & 0.0 & 0.0 & 0.0 \\
& control & 67.0 & 24.7 & 7.1 & 1.2 & 0.0 \\
\hline \multirow{3}{*}{37 -day-age } & $\mathrm{NH}_{4} \mathrm{~F}$ & 74.1 & 23.7 & 1.5 & 0.7 & 0.0 \\
& APF & 78.9 & 19.5 & 1.6 & 0.0 & 0.0 \\
& control & 42.4 & 43.0 & 14.0 & 0.6 & 0.0 \\
\hline \multirow{3}{*}{ 44-day-age } & $\mathrm{NH}_{4} \mathrm{~F}$ & 34.9 & 64.7 & 0.4 & 0.0 & 0.0 \\
& APF & 50.6 & 47.2 & 2.2 & 0.0 & 0.0 \\
& control & 25.4 & 45.7 & 27.5 & 1.4 & 0.0 \\
\hline \multirow{3}{*}{51 -day-age } & $\mathrm{NH}_{4} \mathrm{~F}$ & 28.1 & 66.2 & 5.7 & 0.0 & 0.0 \\
& APF & 41.1 & 57.8 & 1.1 & 0.0 & 0.0 \\
& control & 15.4 & 50.8 & 26.4 & 7.4 & 0.0 \\
\hline
\end{tabular}
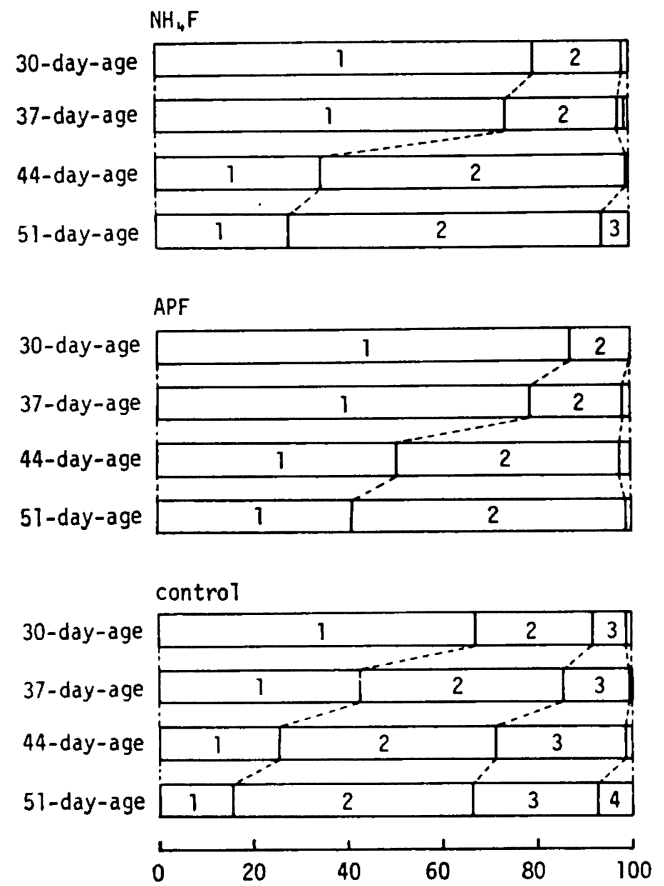

(\%)

Fig. 10 Distribution of each caries grade

Table 9 The status of implantation of $S$. mutans

\begin{tabular}{l|c|ccccc}
\hline & before inoculation & \multicolumn{5}{|c}{ after inoculation } \\
group & 16 & 21 & 26 & 33 & 40 & 47 \\
\hline $\mathrm{NH}_{4} \mathrm{~F}$ & - & + & + & + & + & + \\
APF & - & + & + & + & + & + \\
control & - & + & + & + & + & + \\
\hline
\end{tabular}

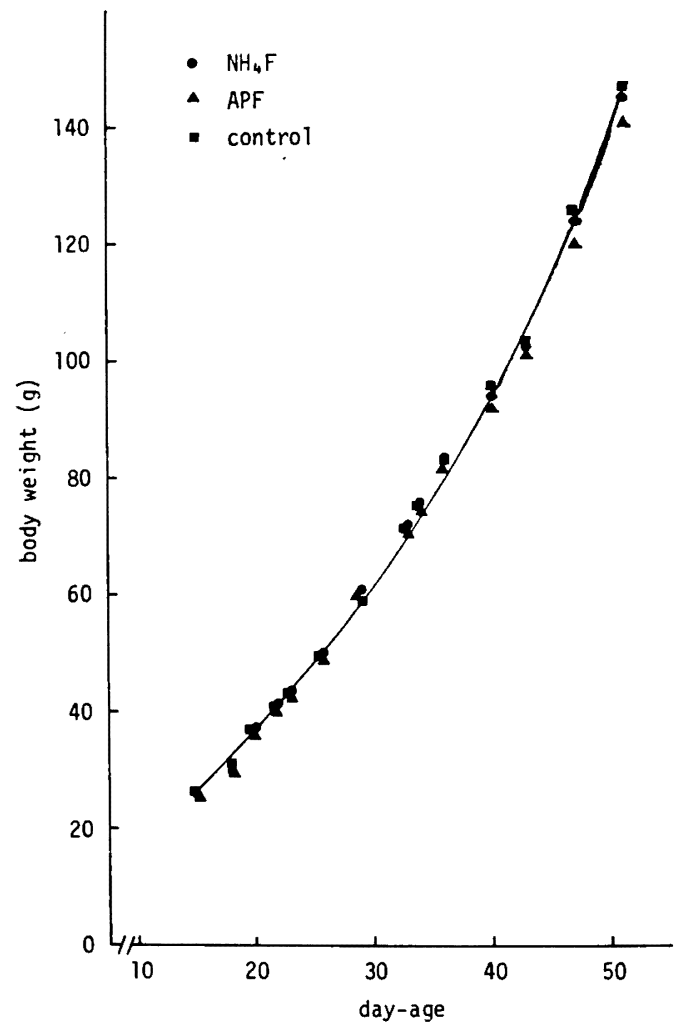

Fig. 11 The mean body weight gain

盛んに行なわれるようになっている。Caslavska ら ${ }^{20)}$ は $0.05 \mathrm{M} \mathrm{H}_{3} \mathrm{PO}$ 、による 1 分間の前処理後, $0.62 \mathrm{MNH}{ }_{4} \mathrm{~F}$ 溶液（pH 4.4）を 3 分間作用させたエナメル質は，同条 件下の $\mathrm{NaF}$ 溶液作用のものよりも取り込まれるフッ素 量がかなり多く，エナメル質表面に $\mathrm{CaF}_{2}$ の生成がみら 
れることを認めている。そして，この生成物は長時間の 人工唾液浸渱後も除去されないことから， NH4F 溶液作 用により生成する $\mathrm{CaF}_{2}$ はエナメル澌とかなり強固に結 合しているのであろうと考察している。

また Wei ら ${ }^{22)}$ は現在フッ化物歯面塗布液として用い られている APF 溶液と比較して, $\mathrm{NH}_{4} \mathrm{~F}$ 溶液 $(\mathrm{pH}$ $\left.5.8,1.23 \% \mathrm{~F}^{-}\right)$は APF 溶液 $\left(\mathrm{pH} 3.0,1.23 \% \mathrm{~F}^{-}\right)$ の $1 / 2.3$ のフッ素取り込みを確認しており，酸による前 処理なしで $\mathrm{pH}$ 5.8の NH、F 溶液作用によるエナメル 兵への多量のフッ素取り込みを認めている。

フッ化物歯面塗布は年 1 回，あるいは半年に 1 回の割 合で行い，塗布時間は 4 分間が通法となっている。現在 用いられている APF 齿面塗布液はフッ素滣度が9,000 $\mathrm{ppm}$ 上高く，また溶液の $\mathrm{pH}$ が3.4であり，低学年の児 童にとっては負担が大きいように思われる。当教室の山 村 ${ }^{281}$ は $\mathrm{APF}$ 溶液と同フッ素浱度, 同 $\mathrm{pH}$ の $\mathrm{NH}$ 、F 溶 液をエナメル梊粉末に作用させ，生成した $\mathrm{CaF}_{2}$ 量から みて $\mathrm{NH}_{4} \mathrm{~F}$ 溶液を用いれば $\mathrm{APF}$ 溶液の $1 / 2$ の棗布時 間で同様の効果が期待できることを示唆している。この 事は言いかえれば同一筀布時間の場合，フッ素洤度を低 下させても同様の効果が期待できることを示している。 このような理由から本研究では, APF 溶液の1/3のフッ 素湦度 $3,000 \mathrm{ppm}$ で, さらに安全性を加味し, 溶液の $\mathrm{pH}$ を 4.4 に調節したリン酸酸性フッ化アンモニウム溶液を 調製し，ヒト intact enamel を用いた基磷的研究と， ラットを用いた動物実験を行い, APF 溶液との比較検 討を行った。

実跧 1 intact enamel を用いて

Intact enamel を材料とし，フッ化物溶液のエナメル 犋に及ほす影翼について検討を行った。

Intact enamel へのフッ素取り込みについての研究で は, Arends 5 ${ }^{00}$ は $\mathrm{pH} 4.0$ APF 溶液と $\mathrm{NH}_{4} \mathrm{~F}$ 溶 液を作用させ， $\mathrm{NH}_{4} \mathrm{~F}$ 溶液作用の方が permanent fluoride の吸収が幾分多いことを報告している。さらに Gron ら201 は $\mathrm{NaF}, \mathrm{KF}, \mathrm{NH}_{4} \mathrm{~F}$ 溶液についてエナメル 兵へのフッ素取り込みの比較を行っており， $\mathrm{pH} 4.6$ の $\mathrm{NH} 4 \mathrm{~F}$ 溶液にリン酸アンモニウムを加えた溶液がエナ メル犋へのフッ素浸透が最も大きく，フルオロアパタイ 卜の生成量も多いことを報告している。本研究において も， $\mathrm{NH}_{4} \mathrm{~F}$ 溶液の方がフッ素濃度が低いにもかかわら ボ，APF 溶液より多量のフッ素取り込みが認められた。

フッ化物溶液作用エナメル倎の酸溶解性試験では, 連 䌇脱灰により表屏から内屏へのリン溶出量を測定したも のであるが，耐酸性獲得勃果は $\mathrm{NH}_{4} \mathrm{~F}$ 群で大きく，内
層にまで及ぶことが示された (Fig. 4)。このことはエナ メル澌表面の SEM 像からも明らかであり, 溶液作用後 の $\mathrm{NH}$ 、F 群と APF 群はいずれもかなりの量の沈着物 がみられたが形態が異なり， $\mathrm{NH}_{4} \mathrm{~F}$ 群エナメル澌の沈着 物は細粒で厚みがあった（Fig．6）。また，表面の沈 着物の性状について, 酸溶解性試験後のエナメル表面の SEM 観察を行ったところ, APF 群でもわずかにエナ メル兵の脱灰像が観察されたが， NH、F 群では表面に顆 粒状の沈着物が明らかに残存しており，酸抵抗像を示し た (Fig. 6)。同様の所見は EPMA の酸脱灰像の成績 からも明らかである。すなわち，APF 群では表層から 数 $\mu \mathrm{m}$ まで $\mathrm{CaK} \alpha$ 線, $\mathrm{PK} \alpha$ 線の低下が認められ脱灰 像が䧽察されたが， NH。F 群では酸溶解性試験後でも最 表層に $\mathrm{CaF}_{2}$ 由来と考えられる $\mathrm{FK} \alpha$ 線の鋭いピークが 観察され，さらに表層下 $30 \mu \mathrm{m}$ の梁さの所では $\mathrm{CaK} \alpha$ 線，PK $\alpha$ 線の著しい低下が示され，表層下脱灰像が翟 められた (Fig. 7)。Caslavska ら (1) は1.5 $\mathrm{MNH}_{4} \mathrm{~F}$ 溶液 (pH 7.0) を 5 分間作用させたエナメル片に $\mathrm{CaF}_{2}$ 生成 を認めており，作用後エナメル犋表首を $1 \mathrm{M} \mathrm{KOH}$ 溶 液で洗浄すると $\mathrm{CaF}_{2}$ は除去されると報告している。ま たWefel ら 25) は APF 溶液作用エナメル倎で生成され た $\mathrm{CaF}_{2}$ は48時間の人工唾液洗浄，あるいは $1 \mathrm{M} \mathrm{KOH}$ 溶液洗浄で安易に除去されるが， $\mathrm{NH}_{4} \mathrm{~F}$ 溶液（1.23\% $\mathrm{F}^{-}, \mathrm{pH}$ 4.2) 作用で生成した $\mathrm{CaF}_{2}$ は $1 \mathrm{M} \mathrm{KOH}$ 溶液 洗浄では除去されるが，人工喠液洗浄では残留すること を示している。一方, 可児ら(2)の報告では APF 溶液作 用エナメル犋とリン酸酸性フッ化アンモニウム溶液作用 エナメル兵の $1 \mathrm{M} \mathrm{KOH}$ 溶液洗浄後のエナメル倎表面 の SEM 観察では, NH、F 溶液作用の方が明らかに沈着 物に厚みがあり, $1 \mathrm{M} \mathrm{KOH}$ 溶液48時間洗浄後にも沈着 物はまだ残留することを示している。この様に APF 溶 液作用と $\mathrm{NH}_{4} \mathrm{~F}$ 溶液作用で生成された $\mathrm{CaF}_{2}$ は形態が 異なり, $\mathrm{NH}_{4} \mathrm{~F}$ 溶液で生成された $\mathrm{CaF}_{2}$ はかなり溶出し にくいものと思われる。Wei ら ${ }^{23)} \mathrm{NH}$ F 溶液はエナ メル啠中に多量の $\mathrm{CaF}_{2}$ を生成するが，量が多いため 洗浄されにくいことを示している。

以上の報告とあわせて, 本研究の $\mathrm{NH}_{4} \mathrm{~F}$ 溶液作用エ ナメル梊へのフッ素取り込み量の增大は多量の $\mathrm{CaF}_{2}$ 生 成によるものであり，酸抵抗性の獾得も $\mathrm{CaF}_{2}$ の生成に よるものであると考えられる。

実験 2 ラットを用いた動物実験

リン酸酸性フッ化アンモニウム溶液 $\left(3,000 \mathrm{ppmF}^{-}\right.$， $\mathrm{pH}$ 4.4) の歯面叙布によるう蝕予防効果について，ラッ 卜を用いた動物実験系でその発生予防効果と進行㧕制効 
果の両面から検討を行った。

ラットは従来より当教室で行っていよように好う舯発 生条件下で飼育したものを用いた ${ }^{87)}$ 。すなわち離乳直後 よりう蝕誘発性試料を与え ${ }^{43)}$, S. mutans GS-5 株を接

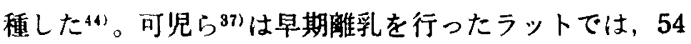
日龄ですでに被検歯のほとんどの unit にう強発生が認 められ，フッ化物溶液凃布による予防効果が確認できな かったと述べている。本実験では30日龄より51日龄まで の実験期間でう蜆発生予防効果を比較するために，ラッ トは早期强制離乳ではなく自然離乳とした。

う蝕発生状況（caries incidence）をみると，フッ化 物溶液染布群は対照群に比べてう強発生が少なかった (Fig. 8)。しかしフッ化物溶液塗布群間でもう触発生状 況は異っており，APF 群は日路が少ないほど䍜患率は 低いが，日龄が進むに従ってほほ㨁線的に増加していく 傾向がみられた (Table 6)。このことはWellock ら の APF 溶液は特にう触の初発に対し予防効果があると いう報告と一致する。一方 NH、F 群では APF 群と同 程度にはう触予防効果は認められなかったが, 対照群に 比べると51日龄では危険率 $0.1 \%$ 以下で統計的に有意の う蜆発生予防効果が観察された（Table 5)。

ラット臼歯の裂漂部は軽度に石灰化しており ${ }^{46)}$ ， ラッ トの歯牙萌出時に存在する裂氀底部のエナメル犋末石灰 化部分の石灰化は日数の経過とともに二次的にすすむと いわれている47)。また Silverstone48) はフッ素による石 灰化促進作用に注目している。そこで今回の動物実験で は㕍乳後直ちにフッ素塗布を行い, う触進行抑制効果を 観察した。対照群では30日龄よりすでに重症う蜆を示す grade 4 のものが存在し，日龄がすすむにつれてう蝕の 程度は重症になった（Fig. 10）。一方，フッ化物溶液塗 布群では対照群と比較してう強の程度は低く, 統計的に 有意の差をもってう䖪進行㧕制効果が認められた（Fig. 9)。

ラットを用いた $\mathrm{NH}_{4} \mathrm{~F}$ 溶液塗布実験では, Gron ら ${ }^{49}$ が $1,000 \mathrm{ppm}$ のフッ素を含む $\mathrm{NaF}$ 溶液と $\mathrm{NH}_{4} \mathrm{~F}$ 溶液 を $\mathrm{pH} 5$ と $\mathrm{pH} 7$ で比較しており,リン酸で $\mathrm{pH} 5$ にし た $\mathrm{NH}_{4} \mathrm{~F}$ 溶液で最も高いう触抑制効果がみられ、 $\mathrm{NaF}$ と $\mathrm{NH}_{4} \mathrm{~F}$ のう蝕抑制効果の違いは cation の大きさによ るものであると述べている。Caslavska ら50)はフッ素洤 度 $30 \mathrm{ppm}, \mathrm{pH} 7.0 の \mathrm{NH}, \mathrm{F}$ 溶液と $\mathrm{NaF}$ 溶液を飲料水 に混入して, ラットのう強抑制効果について 検討を 行 い, $\mathrm{NH}_{4} \mathrm{~F}$ 群の方が勃果が大きいことを認めている。ま た, DePaola ら ${ }^{51)}$ は児童に $\mathrm{NH}_{4} \mathrm{~F}$ 溶液 $\left(1,000 \mathrm{ppmF}^{-}\right.$, $\mathrm{pH} 4.4)$ と $\mathrm{NaF}$ 溶液 $\left(1,000 \mathrm{ppmF}^{-}, \mathrm{pH} \mathrm{4.4)} 2\right.$ 年
間洗口させたところ，新萌出歯に対するう触発生の予防 勃果は $\mathrm{NH}$. F 群で有意に大きいことを認めている。こ の様に同フッ素浱度, 同 $\mathrm{pH}$ の溶液では臨床上でも $\mathrm{NH}_{4} \mathrm{~F}$ 溶液の方が高い効果が認められている。

本研究ではフッ素灌度 $3,000 \mathrm{ppm}, \mathrm{pH} 4.4$ のリン酸酸 性フッ化アンモニウム溶液のう蝕抑制勃果をフッ素跟度 9,000ppm, pH 3.4の APF 溶液と比較検討した。 $\mathrm{NH}_{4} \mathrm{~F}$ 群ではフッ素浱度が APF 溶液の1/3にもかかわらず, う䖵発生予防効果, う軣進行抑制効果が認められ, 特に 進行抑制効果においては塗布回数が增加するにつれ， APF 溶液と同程度の効果を持つことが喼められた。

以上, 実験 1 , 実験 2 の成績からフッ素灌度 3,000 $\mathrm{ppm}, \mathrm{pH} 4.4$ のリン酸酸性フッ化アンモニウム溶液は intact enamel に対し多量の $\mathrm{CaF}_{2}$ 生成により䩂酸性を 増強させること，またラットに対してはう触抑制奻果を 獾得させることが認められたことから，フッ化物齿面塗 布液としての臨床応用の可能性が示された。

\section{結論}

リン酸酸性フッ化アンモニウム溶液 (フッ素凝度 3,000 $\mathrm{ppm}, \mathrm{pH}$ 4.4) のフッ化物站面塗布液としての有効性と 臨床応用の可能性を追求することを目的とし，in vitro の実験としてヒト intact enamel を材料とし, フッ素取 り込み，酸溶解性試験およびエナメル質表面の観察を行 い, in vivo ではラット実験う蝕系を用いてう蝕抑制効 果を観察し, それぞれ APF 溶液と比較検討を行った結 果, 次の成績を得た。

1. フッ化アンモニウム溶液作用により intact enamel 中のフッ秦量は增加した。

2. フッ化アンモニウム溶液作用では APF 溶液作用 と比較してもリンの溶出が抑えられており, 高い酸抵抗 性獾得が認められた。また，その効果はエナメル質内層 におよぶことが示された。

3. フッ化アンモニウム溶液作用では，エナメル質表 面に細かい粒子が緻密に重なりあった SEM 像が観察 され，また180分間の酸溶解性試験後でも表面に顆粒状 沈着物の存在を認めた。

4. X線マイクロアナライザの結果からも, フッ化ア ンモニウム溶液作用エナメル澌は APF 溶液作用群より 数倍高いフッ素取り込みを認め, 酸溶解性試験後でも表 首より $10 \mu \mathrm{m}$ の哚さまでフッ素が取り込まれていること が示された。

5. ラット実験う蝕において，フッ化アンモニウム溶 液の歯面染布は統計的にも有意の差で，う蝕の発生予 
防, 進行抑制効果が認められ, APF 溶液と同程度の効 果を恝めた。

6. フッ化アンモニウム溶液の歯面塗布ではラットの 健康状態への影筥は認められなかった。

以上のことより，フッ秦渡度 $3,000 \mathrm{ppm}, \mathrm{pH} 4.4$ の ン酸酸性フッ化アンモニウム溶液は, 現在臨床応用され ているリン酸酸性フッ化ナトリウム溶液の $1 / 3$ のフッ素 灌度でもう蝕予防効果が期待され, 臨床応用の可能性の あることが示唆された。

稿を終えるにあたり，本研究課題を与えられ，終始御 想篤なる御指導, 御校閲を賜わりました口腔街生学講坐 の可児瑞夫主任数授，ならびに研究の咶画と遂行にひと かたならぬ御指導，御助言を睗りました社会画科学煐座 の可児德子教授に深甚の䝰意をささげます。同時に，種 タ御協力をいただいた口腔衛生学教室の諸氏に心より感 柇申し上げます。

また，S. mutans 提助いただきました朝日大学齿学 部口腔細菌学教室の並河勇教授に御礼申し上げます。

\section{文献}

1）领境喜一，岡田昭五郎：フッ化物とその応用， 医齿萖出版，東京，1973，143-194頁.

2) Stearns, R. I. : Incorporation of nonfluoride and fluoride prophylactic pastes and APF gels, J. Dent. Res., 52; 30-35, 1973.

3）可児瑞夫：学校科における程予防対策，国 際齿科ジャーナル，3；171-177，1977.

4）可児瑞夫：フッ化物洗口法の位圈つけ，齿界展 望, $50 ； 1033-1045,1977$.

5）可児瑞夫：触予防のためのフッ化物洗口法, 口腔衙生会誌, $27 ; 131-147,1977$.

6) Leske, G. S. : Guidelines for establishing a fluoride mouthrinsing caries prevention program for school children, Public Health Rep., 92 ; 240-244, 1977.

7）河野 節：酸性フッ素リン酸溶液齿面染布法の う䖵予防勃果に関する研究一二重目検法による 検討一, 忮歯学誌, $10 ; 346-365,1980$.

8) Triol, C. W., Kranz, S. M., Volpe, A. R. and Frankl, S. N.: Anticaries effect of a sodium fluoride rinse and a MFP dentifrice in a nonfluoridated water area: A thirthmonth study, Clinical Preventive Dentistry, $2 ; 13-15,1980$.

9）磯崎篤則：学校歯科保健活動へのフッ化物局所 応用法導入によるう蚛予防に関する研究，口腔 衛生会誌, $34 ; 598-631,1984$.

10) Caslavska, V., Moreno, F. C. and Brudevold,
F.: Determination of the calcium fluoride formed from in vitro exposure of human enamel to fluoride solutions, Arch. Oral Biol., 20 ; 333-339, 1975.

11）可児徳子, 可児瑞夫, 富松早苗, 新海研志, 河 野 節，人保告昭：エナメル澌におよぼすフッ 化物洗口液の影掣について 第1 報 X線回 折法による検郡. 口腔衛生会誌, $27 ; 38-45$, 1977.

12）可児徳子、可児瑞夫, 富松早苗, 新海研志, 河 野 節，久保惒昭：エナメル梊におよぼすフ 化物洗口液の影辢について 第2 報フッ素取 込量と流出量について，口腔衛生会誌，27； 93-99, 1977.

13）人保憲昭：低溚度フッ化物洗口液のエナメル澌 粉末におよぼす影知に関する研究，口腔衛生会 菬, $32 ; 390-402,1982$.

14）中西国夫：フッ化物溶液作用エナメル梊におけ る生成フルオロアパタイトのX線回折法による 研究，口腔街生会誌，34；109-123，1984.

15）米林光三：象牙啠 Apatite に生成された $\mathrm{CaF}_{2}$ の反応に関するX線結晶学的研究, 阪大菌学 誌, $12 ; 79-93,1967$.

16）可児德子, 河合庄治郎, 森脇豊, 山賀礼一： アパタイト結晶の格子不整におよぼす $\mathrm{CaF}_{2}$ の 影響につい下，歯理工誌，11；92-96，1970.

17）可児徳子：フッ化物によるアパタイト結晶の格 子不整修復に関するX $\mathrm{X}$ 線結晶学的研究, 阪大菌 学誌, $15 ; 42-56,1970$.

18）須贺昭一：齿・科学とその周辺, 共立出版, 東 京, 1981，225-239頁.

19）可児瑞夫，可児徳子：う強予防のためのフッ化

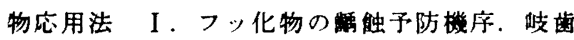
学誌, $12 ; 1-12,1985$.

20) Caslavska, V., Brudevold, F., Vrbic, V. and Moreno, E. C. : Response of human enamel to topical application of ammonium fluoride, Arch. Oral Biol., 16 ; 1173-1180, 1971.

21) Wei, S. H. Y.: Enamel microsampling technique for assessing fluoride uptake from topical fluoride treatments, In vitro. J. Dent. Res., 52 ; 1268-1272, 1973.

22) Wei, S. H. Y. Soboroff, M. D., Wefel, J. S. and Wolfson, S. : Relative effects of ammonium fluoride and acidulated phosphate fluoride solutions on human enamel, J. Dent. Res., 54 ; 1234, 1975.

23) Wei, S. H. Y., and Schulz, E. M. Jr. : In vivo microsampling of enamel fluoride concentrations after topical treatments, Caries Res., 9 ; 50-58, 1975.

24) Gron, P. and Caslavska, V.: Fluoride deposition in enamel from application of sodium, potassium or ammonium fluoride, Caries Res., 15 ; 459-467, 1981. 
25) Wefel, J. S. and Harless, J. D.: The effect of topical fluoride agents on fluoride uptake and surface morphology, J. Dent. Res., 60 ; 1842-1848, 1981

26) 山村利貞：リン酸酸性フッ化アンモニウムのエ ナメル質におよほす影警について，口舼衛生会 誌, $35 ; 330-344,1985$.

27) 加藤裕久, 飯野新太郎, 広瀬晃子, 德本能弘, 破崎䉆則, 可児徳子, 可児瑞夫：フッ化アンモ ニウム溶液に上るエナメル梊粉末の $\mathrm{CaF}_{2}$ 生成 と酸溶解性につい下, 口腔街生会誌, 37 ; 478479, 1987.

28）新谷裕久：低䈨度フッ化アンモニウム歯面整布 溶液のエナメル啠粉末に及ほす影䍌について。 口腔簿生会誌, 40；270-286, 1990.

29) Wefel, J. S.: Artificial lesion formation and fluoride uptake after $\mathrm{TiF}_{1}$ applications, Caries Res., 16 ; 26-33, 1982.

30) McCann, H. G.: Determination of fluoride in mineralized tissue using the fluoride ion electrode, Arch. Oral Biol., $13 ; 475-$ 477, 1968.

31) Chow, L. C., Guo, M. K., Hsieh, C. C. and Hong, Y. C.: Apatitic fluoride increase in enamel from a topical treatment involving intermediate $\mathrm{CaHPO}_{4} \cdot 2 \mathrm{H}_{2} \mathrm{O}$ formation, an in vivo study, Caries Res., $15 ; 369-376$, 1981.

32) Dryer, R. L., Tammes, A. R. and Routh, J. I.: The determination of phosphorous and phosphatase with $\mathrm{N}$-phenyl-p-phenylendiamine, J. Biol. Chem., 225 ; 177-183, 1957.

33） Navia, J. M.：（河村洋二郎監訳）：画科学研 究のための動物実跨法, 学建蓄院, 東京, 1979 (第 1 版) 225-258，232-234頁.

34) Hamada, S. and Slade, H. D. : Biology, immunology and cariogenicity of Streptococcus mutans, Microbiol. Rev., 44 ; 331-384, 1980.

35）可児德子, 広瀬晃子, 磯崎第則, 伊川英二, 新 谷裕久, 可児瑞夫：フッ化チタンアンモニウム 溶液に上るラット実駼う触の予防勃果につい て, 口腔衛生会誌, 39; 16-26, 1989.

36) Gold, O. G., Jordan, H. V. and Houte, J. V.: A selective medium for streptococcus mutans, Arch. Oral Biol., 18 ; 1357-1364, 1973.

37）可児瑞夫，可児徳子，饭野新太郎，広瀬晃子, 磯崎籊則，伊川英二，奥野雅典，加藤裕久：フ ッ化チタンアンモニウムによるラット実検う䖵 抑制効果。只腔徫生会誌， 37 ; 63-71， 1987.

38) Manly, R. S. and Bibby, B. G.: Substance capable of decreasing the acid solubility of tooth enamel, J. Dent. Res., 28 ; 160-171, 1949.

39) Mühlemann, H. R., Schmid. H. and König,
K. G. : Enamel solubility reduction on studies with inorganic and organic fluorides, Helv. Odont. Acta, 1 ; 23-33, 1957.

40) Arends, J. and Schuthof, J. : Fluoride content in human enamel after fluoride application and washing - an in vitro study, Caries Res., 9 ; 363-372, 1975.

41) Caslavska, V., Gron, P., Stern, D. and Skobe, Z. : Chemical and morphological aspects of fluoride acquisition by enamel from topical application of ammonium fluoride with ammonium monofluorophosphate, Caries Res., 16 ; 170-178, 1982.

42) Kani, T., Shimizu, M., Fukuoka, Y., Iino, S. and Kani, M. : The effect of ammonium titanium fluoride on human enamel-III, JADR 32nd annual meeting, abst., No. 41, 1984 .

43) Menaker, L. and Navia, J. M. : Effect of under nutrition during the perinatal period on caries development in the rat.: IV Effects of differential tooth eruption and exposure to a cariogenic diet on subsequent dental caries incidence, J. Dent. Res., 52 ; 692-697, 1973.

44) Gibbons, R. J., Berman, K. S., Knoettner, P. and Kapsimalis, B.: Dental caries and alveolar bone loss in gnotobiolic rats infected with capsule forming Streptococci of human origin, Arch. Oral Biol., 11 ; 549-560, 1966.

45) Wellock, W. D., Maitland, A. and Brudevold, F.: Caries increments tooth discoloration and state of oral hygiene of children viven single annual applications of acidula. ted phosphate fluoride and stannous fluoride, Arch. Oral Biol., 10 ; 453-460, 1965.

46) Brinner, W. W., Francis, M. D. and Widder, J. S.: Factors affecting the rate of post-eruptive maturation of dental enamel. Calc. Tiss. Res., 7 ; 249-256, 1971.

47) Francis, M. D. and Brinner, W. W.: The development and regression of hypomineralized areas of rat molars, Arch. Oral Biol., 11 ; 349-354, 1966.

48) Silverstone, L. M.: Chapter 11 Fluoride and remineralization, Edied by Wei, S. H. Y.: Clinical Uses of Fluorides, Lea \& Febiger, 1985. 可児瑞夫監訳 : フッ化物の臨床応 用. 医歯薬出版，東京，1988，167-190頁。

49) Gron, P., Caslavska, V., Tamura, T. and Kent, R.: The caries inhibitory effect of repeated topical applications of $\mathrm{NaF}$ or $\mathrm{NH}_{4} \mathrm{~F}$ in rodents, Caries Res., 21 ; 346-352, 1987.

50) Caslavska, V., Gron, P., Picard, M. and Kent, R. : Comparison of the relative ca- 
ries-inhibitory effect of sodium and ammonium fluoride administered in the drinking water to rats, Caries Res., 21 ; 62-67, 1987.

51) DePaola, P. F., Soparkar, P., Foley, S., Bookstein, F. and Bakhos, Y.: Effect of high-concentration ammonium and sodium fluoride rinses on dental caries in school children, Community Dent. Oral Epidemiol., 5 ; 7-14, 1977. 